\title{
SOLAR ENERGY COLLECTION, STORAGE AND UTILIZATION FOR DOMESTIC PURPOSES
}

\author{
Darwesh, M. R.* and Ghoname, M. S.**
}

\section{ABSTRACT}

Two solar radiation models (Duffie \& Beckman and ASHRAE) were computed and evaluated on the middle area of Coastal Delta, Egypt (latitude and longitude angles are $30.49^{\circ} \mathrm{N}$ and $30.59^{\circ} \mathrm{E}$, respectively). A comparison study of the two models was conducted using measured incident solar radiation on a horizontal plane to assess the proper model can dependable be used for different solar applications. To compute the total incident solar radiation on inclined surface, two different tilt angles $\left(30.5^{\circ}\right.$ and $\left.45.3^{\circ}\right)$ were functioned all over the year. The comparison study between the two estimation models and the measured values of incident solar radiation showed that, the highest value of $R 2$ at horizontal and tilted surface using Duffie and Beckman model. Useful heat gain for the measured solar radiation was ranged between 6.54 and $8.82 \mathrm{kWh}$ and calculated solar radiation by Duffie and Beckman model, was 5.99 and $7.34 \mathrm{kWh}$ and calculated solar radiation by ASHRAE model, was 6.79 and $9.0 \mathrm{kWh}$ with tilt angle $30.5^{\circ}$. While, at tilt angle $45.3^{\circ}$ useful heat gain for measured solar radiation was ranged between 7.89 and 9.06 $k W h$. The electrical energy for heating domestic water ranged from 7.61 to $10.12 \mathrm{kWh}$ for winter months. This study gave the best way by calculated solar radiation replacement of expensive solar radiation instruments and always it fixed in weather stations and also, this study gave an idea to use the solar water heaters for domestic purposes.

Keywords: position of the sun, calculated solar radiation, solar heaters

\section{INTRODUCUTION}

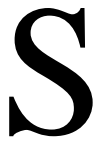
olar energy is an abundant permanent and environmentally compatible energy source in the world. The amount of incident solar radiation on the solar receivers (solar collectors or photovoltaic) on hour, day, week, and month has more importance for determining the type of application using solar energy.

\footnotetext{
* Assistant prof of Agric. Eng. Dept., Fac. of Agric., Tanta Univ.

** Lecturer of Agric. Eng. Dept., Fac. of Agric., Tanta Univ.
} 
Basically, the intensity of solar radiation differs from location to location and season to another. Therefore, it should be measured or calculated the solar radiation to determine the requirement heat energy, which can operate any system. Nevertheless, the measured data demand measurement devices which are not always available due to uncertain price rise of solar radiation instruments. These instruments are generally connected with the weather stations to measure the incident solar radiation on a horizontal plane.

This measuring data require some manipulates and developments to compute the incident solar radiation on tilted surfaces. Moreover, the developed model may assist researchers to solve research problems or newly project study needs information for planning the scientific methodology in order to achieve the goal of research or project. Therefore, estimation of incident solar radiation is necessary for all activities that associated with applications of solar energy. These values of incident solar radiation are differing between the two models, which gave various results. All models need the pyranometer to calibrate or compare the computations with real readings. The most popular models are; Duffie \& Beckman, and ASAHARE, which used for this purpose. Solar radiation estimating models are one of the best method to carry out a good solar potential investigation (Azadeh et al., 2009). Darwesh et al., 2010 analyzed the thermal performance of two different areas of flat plate solar collector. These experiments conducted at latitude and longitude angles of $30.95^{\circ} \mathrm{N}$ and $30.09^{\circ} \mathrm{E}$, respectively. The daily average total solar radiation flux incident on the horizontal and vertical surfaces during this experimental work was 4.066 and $5.623 \mathrm{kWh} / \mathrm{m}^{2}$. The water temperature in the storage tank of different solar collectors is ranged between $50^{\circ} \mathrm{C}$ to $70^{\circ} \mathrm{C}$ which is quite sufficient for domestic water use (Amrutkar et al., 2012). In solar applications, one of the most important parameters needed is the long-term daily average global irradiation. For regions where no actual measured values are available, a common practice is to estimate the daily average global solar radiation using appropriate empirical correlations based on the measured relevant data at research in question (Besharat et al., 2013). The flat plate solar collector has an overall thermal efficiency ranges between 50 to $60 \%$ which appropriate for the moderate temperature $\left(40-60^{\circ} \mathrm{C}\right)$ applications 
(Chasma-ard et al., 2014). Pyranometer is the most reliable device for measuring and recording the amount of solar radiation that reaches on the earth's surface, epically in arid and semi-arid regions at which the number of solar observations is poor and solar radiation data is not available (EI Mghouchi et al, 2014). Therefore, a variety of mathematical and empirical models have been proposed in their study for both the subdivision of horizontal solar radiation into direct and diffuse components (horizontal diffuse irradiance models) and for the calculations of irradiation on tilted surfaces (irradiance models for tilted surfaces). They used solar radiation data in order to account for the solar heat gains or to evaluate day lighting issues in building energy. Finally, the model provided more reliability of solar radiation data can be choice (Prada et al., 2014).

The thermal performance of evacuated tube solar collector type was examined and tested by Fouda et al. (2016) at latitude and longitude angles of $30.5^{\circ} \mathrm{N}$ and $30.59^{\circ} \mathrm{E}$, respectively. The solar radiation flux incident on tilted solar collector is an effective element uses to determine the thermal performance of evacuated solar collector. The daily average total solar radiation flux incident on the tilted surfaces was 5.604 and 7.34 $\mathrm{kWh} / \mathrm{m}^{2}$ during winter and summer seasons, respectively. The hourly averages incident solar radiation measured on tilted surface was 701 and $918 \mathrm{~W} / \mathrm{m}^{2}$ during winter and summer seasons, respectively. The higher values for the solar radiation observed at noon were 1247 and $1299 \mathrm{~W} / \mathrm{m}^{2}$. The position of the sun on place in question is represented the importance fundamental to determine these values when measured or calculated. Egypt is endowed abundant amount of direct solar radiation which ranges between 2000 to $3200 \mathrm{kWh} / \mathrm{m}^{2} /$ year from North to South, respectively. The sunshine duration ranges between 9 to $11 \mathrm{~h}$ /day from North to South, with very few cloudy days (Atlas, 2018).

The national strategy of the Egyptian government is in general focused on integrated renewable energy management through various plans started on 2005 and may by the end of 2030 contribution of renewable energy reaches to $20 \%$ of the total generated electricity. In December 2013, the cabinet has declared a resolution to install 1000 photovoltaic rooftop systems (PVRS), on governmental buildings. Total installed capacities is around $15 \mathrm{MW}$, most of these systems are stand-alone to power different 
applications (25\% cell phone networks systems, $5 \% \mathrm{PV}$ power plant grid connection, 27\% lighting systems, $16 \%$ advertising lighting systems, $6 \%$ water pumping systems, $1 \%$ desalination systems, $7 \%$ catholic protection systems and $13 \%$ communication systems. During winter season may obtain an adequate solar radiation resulting in cloudy intensity or adverse conditions. Therefore, to keep the solar domestic heating requirements at required level should be operated an electrical heater when the sun is absent. So, the main objectives of this study are to; compute the hourly average solar radiation flux incident on tilted surface using two different models (Duffie\&Beckman, and ASHARAE), comparison between the measured and computed data, and calculate the heat energy provided by solar heating system using solar collector and combined heating system (electrical heater and solar heater).

\begin{tabular}{|ll|}
\hline$\Phi$ & The latitude angle in degree. \\
$\delta$ & The declination angle in degree. \\
$n$ & The day number from the first of January \\
$\omega$ & Solar hour angle, degree \\
LAT & Apparent solar time, decimal hours, LST Local solar time, decimal \\
& hours, \\
& ET Equation of time decimals minutes, LSM Local standard time \\
& meridian, decimal degree arc l \\
LON & Local longitude, decimal degree arc \\
$\mathrm{Z}$ & Solar zenith angle, degree. \\
$\psi$ & Solar altitude angle degree and \\
$\gamma \mathrm{S}$ & Solar azimuth angle. degree. \\
$\theta$ & Solar incident angle, degree. \\
\hline
\end{tabular}

\section{MATERIAL AND METHODS}

The experimental work was carried out on the roof of Faculty of Agriculture, Agricultural Engineering Department, Tanta University, Gharbyia Governorate, which located at latitude and longitude angles of $30.49^{\circ} \mathrm{N}$ and $30.59^{\circ} \mathrm{E}$, respectively, during 2018 .

\subsection{Materials}

\section{Evacuated tube solar collector}

Two evacuated tube solar collectors consist of 20 evacuated tubes made of borosilicate glass of $180 \mathrm{~cm}$ long used to provide hot water to a 150 liters horizontal storage tank. Evacuated tube composed of two coaxial 
borosilicate glass tubes jointed at the top and sealed at the bottom under vacuum. The hot water gained accumulated in the storage tank. One evacuated tube solar collector is mounted on a movable steel frame to adjust the tilt angle at $45.3^{\circ}$ and the tilt angle of the other solar collector was adjusted at $30.5^{\circ}$. Each tube of the evacuated solar collector contains 2.6 liters of water. The inner tube contains the water to be heated and its exterior surface is coated with a suitably dark absorbing material (nitrite aluminum) for collecting the maximum possible incident solar radiation which is converted into heat and transferred to working fluid (water). The space between the outer and inner tube is evacuated and used as a thermal insulator to reduce convection and conduction heat losses. Thus, the thermal trapping (greenhouse effect phenomena) continuously occurring due to the solar energy available inside the tube. The technical specification of evacuated tubes solar collector (ETC) from the procedure factory is summarized and listed in Table (1).

Table (1): Specification of evacuated tubes solar collector (ETC)

\begin{tabular}{|l|l|}
\hline Parameters & ETC \\
\hline Effective transmittance, $\tau$, decimal & 0.91 \\
Effective absorptance, $\alpha$, decimal & 0.90 \\
Optical efficiency $(\alpha \tau)$, decimal & 0.819 \\
\hline Overall heat transfer coefficient, $\mathrm{U}_{\mathrm{o}}, \mathrm{W} / \mathrm{m}^{2} \mathrm{~K}$ & 1.7 \\
\hline Net solar collector surface area, $\mathrm{Ac}, \mathrm{m}^{2}$ & 1.5 \\
\hline
\end{tabular}

\subsubsection{Instrumentations}

\section{Solar power meter}

A solar power meter was used to measure the incident solar radiation on tilted and horizontal surfaces during the experiments. Solar power meter has a range of $0-1999 \mathrm{~W} / \mathrm{m}^{2}$. Also, the resolution and accuracy of 1 $\mathrm{W} / \mathrm{m}^{2}$ and $< \pm 3 /$ year, respectively.

\subsubsection{Measurements}

\section{Solar radiation}

The incident solar radiation on horizontal plane and inclined surface was measured using solar power meter. The inclined surface which included two different tilt angles of $30.5^{\circ}$ and $45.3^{\circ}$ was used. A $30.5^{\circ}$ tilt angle equal to the latitude angle of the experiment site. A $45.3^{\circ}$ was selected based on an average of the optimum tilt angles at noon during winter months. These tilt angles selected as $30.5^{\circ}$ that equal the latitude angle. 
Meanwhile, the tilt angle of $45.3^{\circ}$ selected by (Darwesh, 2015) who calculated the optimal tilt angle by equation 1 for each winter months in the same site of the present study and he took the average values which produced the second tilt angle. The previous optimums tilt angles were calculated for the stationary non-tracking solar collector, using the following equation (Duffie and Beckman, 2006):

$$
\beta_{\mathrm{o}}=\Phi-\delta \text {, degree }
$$

\subsection{Methods:}

\section{Hourly average solar radiation}

1- Hourly total incident solar radiation on horizontal and tilted surfaces using ASHRAE Model

The American society of Heating, Refrigerating and Air-Conditioning Engineers (ASHARAE, 2005) has been modified an approach for computing the hourly average total solar radiation flux incident on a tilted, vertical, and horizontal surfaces. The total short-wave radiation, $\mathrm{I}_{\mathrm{T}}$, reaching a terrestrial surface is the sum of the direct solar radiation, $\mathrm{I}_{\mathrm{D}}$, the diffuse sky radiation, $I_{d}$, and the solar radiation reflected from surrounding surfaces, $\mathrm{I}_{\mathrm{r}}$, The equations of ASHARAE model as following:

$\mathrm{I}_{\mathrm{T}}=\mathrm{I}_{\mathrm{D}}+\mathrm{I}_{\mathrm{d}}+\mathrm{I}_{\mathrm{r}}, \mathrm{W} / \mathrm{m}^{2}$

A set of steps are required for computing all the factors on the right handside of Equation (2).

\section{Direct total solar radiation (ID)}

$$
\mathrm{I}_{\mathrm{D}}=\mathrm{I}_{\mathrm{DN}} \cos (\theta), \mathrm{W} / \mathrm{m}^{2}
$$

\section{Direct normal solar intensity (I}

$\mathrm{I}_{\mathrm{DN}}=\mathrm{A} \exp \left[-\frac{\mathrm{B}}{\sin \psi}\right], \quad \mathrm{W} / \mathrm{m}^{2}$

Where, A, is the apparent solar irradiation at air mass $=0$, in $\mathrm{W} / \mathrm{m}^{2}, \mathrm{~B}$, is the atmospheric extinction coefficient, decimal, $\psi$, is the solar altitude angle, in degree.

\section{Diffuse solar radiation from a clear sky $\left(I_{d}\right)$}

$\mathrm{I}_{\mathrm{d}}=\mathrm{C} \mathrm{I}_{\mathrm{DN}} \mathrm{F}_{\mathrm{ss}} \quad, \quad \mathrm{W} / \mathrm{m}^{2}$

Where, $\mathrm{C}$, is the diffuse solar radiation factor and, $\mathrm{F}_{\mathrm{ss}}$, is the angle factor between the surface and the sky. 
$\mathrm{F}_{\mathrm{ss}}=\cos ^{2}\left(\frac{\beta}{2}\right), \quad$ decimal

Where, $\beta$, is the tilt angle measured upward from the horizontal plane.

\section{Solar radiation diffusely reflected from the ground $\left(I_{\mathbf{r}}\right)$}

The ground-reflected diffuse solar radiation flux incident on any surface may be estimated by

$$
\mathrm{I}_{\mathrm{r}}=\mathrm{I}_{\mathrm{TH}} \rho \mathrm{F}_{\mathrm{sg}}, \quad \mathrm{W} / \mathrm{m}^{2}
$$

Where. $\mathrm{I}_{\mathrm{TH}}$, is the total solar radiation flux incident on a horizontal plane, in $\mathrm{W} / \mathrm{m}^{2}, \rho=$ reflectance of the foreground, decimal, $\mathrm{F}_{\mathrm{sg}}$, is the angle factor between the surface and the ground, decimal

$\mathrm{I}_{\mathrm{TH}}=\mathrm{I}_{\mathrm{DN}}[\mathrm{C}+\sin (\psi)], \quad \mathrm{W} / \mathrm{m}^{2}$

$\mathrm{F}_{\mathrm{sg}}=\sin ^{2}\left(\frac{\beta}{2}\right)$, decimal

\section{2- Hourly average solar radiation flux incident on horizontal and tilted surfaces using Duffie and Beckman Model}

The quantities of solar radiation flux incident on atilt surface are considered to be very important particularity for solar application such as photovoltaic and solar collectors which tracking the suns rays from sunrise to sunset. For estimating the hourly average solar radiation on a tilt surface, the following steps should be taken into consideration. The following equations by Duffie and Beckman, (2006) precisely determined the solar radiation flux incident on horizontal and tilted surface.

\section{Hourly average total solar radiation incident on a horizontal surface}

The horizontal plane of the ground surface continually receives two components of solar radiation: beam solar radiation and diffuse solar radiation. Sum of these two components is the hourly average total solar on a horizontal surface $\left(\mathrm{I}_{\mathrm{c}}\right)$.

$\mathrm{I}_{\mathrm{c}}=\mathrm{I}_{\mathrm{cb}}+\mathrm{I}_{\mathrm{cd}}, \quad \mathrm{W} / \mathrm{m}^{2}$

Where, $I_{c b}$, is the clear sky beam solar radiation flux incident on a horizontal surface in $\mathrm{W} / \mathrm{m}^{2}$ and, $I_{c d}$, is the diffuse solar radiation flux incident on a horizontal surface in $\mathrm{W} / \mathrm{m}^{2}$.

$\mathrm{I}_{\mathrm{cb}}=\mathrm{I}_{\mathrm{on}} \tau_{\mathrm{b}} \cos \mathrm{z}, \quad \mathrm{W} / \mathrm{m}^{2}$

Where, $\mathrm{I}_{\text {on }}$, is the extraterrestrial solar radiation and is given by : 
$I_{\text {on }}=1353\left[1+0.033 \cos \left(\frac{360 n}{365}\right)\right], \quad W / m^{2}$

$\tau_{\mathrm{b}}$, is the atmospheric transmittance for beam solar radiation.

$$
\tau_{\mathrm{b}}=\mathrm{a}_{\mathrm{o}}+a_{1} \exp \left(-\frac{\mathrm{k}}{\cos \mathrm{z}}\right) \text {, decimal }
$$

The constant, $\mathrm{a}_{\mathrm{o}}, \mathrm{a}_{\mathrm{o}}$ and $\mathrm{k}$, for the standard atmosphere with $23 \mathrm{~km}$ visibility are found from, ao $*$, a1 $*$ and $\mathrm{k}^{*}$, which are given for altitude less than $2.5 \mathrm{~km}$.

$$
\begin{aligned}
& a_{o}^{*}=0.4237-0.00821(6-S)^{2}, \text { decimal } \\
& a_{1}^{*}=0.5055-0.00595(6.5-S)^{2}, \text { decimal } \\
& k^{*}=0.2711-0.01858(2.5-S)^{2}, \text { decimal }
\end{aligned}
$$

Where, $\mathrm{S}$, is the altitude of the observer in $\mathrm{km}$. correction factors are applied to ao $*$, a1 $*$ and $\mathrm{k}^{*}$, to allow for changes in climate types.

$$
\mathrm{I}_{\mathrm{cd}}=\mathrm{I}_{\mathrm{on}} \tau_{\mathrm{d}} \cos \mathrm{Z}, \quad \mathrm{W} / \mathrm{m}^{2}
$$

It is also necessary to estimate the atmospheric transmittance for diffuse solar radiation $\left(\tau_{d}\right)$ to get the total solar radiation flux incident on a horizontal plane.

$$
\tau_{\mathrm{d}}=0.2710-0.2939 \tau_{\mathrm{b}}
$$

\section{$\underline{\text { An hour clearness index }(\mathrm{Kt})}$}

$$
K_{t}=\frac{I}{I_{c}}
$$

Where, I, is the hourly average measured solar radiation on a horizontal surface and, $I_{c}$, is the hourly average estimated solar radiation on a horizontal surface

\section{Beam and diffuse components of solar radiation}

An equation representing this correlation is:-

$$
\begin{array}{lc}
\frac{I_{d}}{I}=1.11+0.0396\left(\mathrm{~K}_{\mathrm{T}}\right)-0.789\left(\mathrm{~K}_{\mathrm{T}}\right)^{2} & \text { for } 0.48 \leq \mathrm{K}_{\mathrm{T}} \leq 1.10 \\
\frac{I_{d}}{I}=0.20 & \text { for } \mathrm{K}_{\mathrm{T}} \geq 1.10
\end{array}
$$




\section{Hourly average total solar radiation on tilted surface}

The total solar radiation on the tilted surface for an hour is the sum of three terms.

$$
\mathrm{I}_{\mathrm{T}}=\mathrm{I}_{\mathrm{b}} R_{b}+\mathrm{I}_{\mathrm{d}} \cos ^{2}\left(\frac{\beta}{2}\right)+\mathrm{I} \rho \sin ^{2}\left(\frac{\beta}{2}\right), \mathrm{W} / \mathrm{m}^{2}
$$

Where, $R_{b}$, is the ratio of beam solar radiation on a tilted surface to that on a horizontal surface. It is given by:

$$
\mathrm{R}_{\mathrm{b}}=\frac{\cos (\phi-\beta) \cos (\delta) \cos (\omega)+\sin (\phi-\beta) \sin (\delta)}{\cos (\phi) \cos (\delta) \cos (\omega)+\sin (\phi) \sin (\delta)}
$$

Solar water heating system assessment

\section{Solar energy available $(\mathbf{Q})$}

$\mathrm{Q}=\mathrm{RA}_{\mathrm{c}} \quad$ Watt

Where, $R$. is the intensity of solar radiation, in $\mathrm{W} / \mathrm{m}^{2}$ and, $A_{c}$, is the collector surface area, in $\mathrm{m}^{2}$

\section{Useful heat gain to storage $\left(Q_{u}\right)$}

The useful heat gain can be calculated from the following equation:

$\mathbf{Q}_{\mathbf{u}}=\mathbf{Q} \eta_{\mathrm{o}}, \quad$ Watt

The overall thermal efficiency $\left(\eta_{\mathrm{o}}\right)$ which was used to compute the useful heat gain is listed in table (2).

Tables (2): Overall thermal efficiency for two different title angles throughout the year.

\begin{tabular}{|l|l|l|l|l|l|l|l|l|l|l|l|l|l|}
\hline \multicolumn{2}{|l|}{ Month } & Jan & Feb & March & April & May & June & July & Aug & Sep & Oct & Nov & Dec \\
\hline \multirow{2}{*}{$\mathrm{C} C$} & $30.5^{\circ}$ & 70 & 68 & 69 & 68 & 69 & 71 & 68 & 69 & 72 & 69 & 67 & 65 \\
\cline { 2 - 25 } & $45.3^{\circ}$ & 71 & 69 & 69 & 68 & 67 & 68 & 66 & 67 & 70 & 67 & 69 & 67 \\
\hline
\end{tabular}

Domestic solar water capacity and number of family consumed it

The hot water which produced by solar collectors can be functioned to provide hot water for domestic purposes, in other words the operating solar collectors in the present study represents a domestic solar water heaters. To achieve this purpose should be calculated the heat which produced by solar collectors to use it by number of persons. (NREL, 2010) gave an equation can be helped to determine the number of persons under this present study.

$Q_{\text {heat }}=\left(C_{h w}\right)(\mathrm{N})\left(\mathrm{C}_{\mathrm{p}}\right)\left(T_{\text {solar }}-T_{a}\right), \mathrm{kJ} / \mathrm{day}$

Where, $Q_{\text {heat, }}$ is the heat requirements quantity to heat water in $\mathrm{kJ} / \mathrm{day}$, $\mathrm{C}_{\mathrm{hw}}$, is the hot water consumed by one person per day (57 litres), $\mathrm{N}$, is the 
number of family, $\mathrm{Cp}$, is the specific heat of water in $\mathrm{kJ} / \mathrm{kg}^{\circ} \mathrm{C}, T_{a}$, is the ambient air temperature and, $\mathrm{T}_{\text {solar, }}$ is the maximum water temperature produced from solar collector, ${ }^{\circ} \mathrm{C}$.

\section{Electrical heating}

When electrical heater as conventional source of heating heats the water in storage tank of solar energy system, the heat energy gain of water can be computed by heat balance equation as follows:

$\mathrm{I}^{2} \mathrm{R}=\left(\mathrm{M}_{\mathrm{s}} / 3600\right) \mathrm{Cp}\left(\mathrm{T}_{\mathrm{s}}-\mathrm{T}_{\mathrm{a}}\right)$

Where, $I^{2} R$, is electrical power in Watt, $M_{s}$, is the water mass in storage tank in $\mathrm{kg} / \mathrm{s}, \mathrm{T}_{\mathrm{s}}$, is the set point temperature of the electrical heater $75^{\circ} \mathrm{C}$, and, $\mathrm{T}_{\mathrm{a}}$ is the monthly average ambient air temperature in ${ }^{\circ} \mathrm{C}$. The monthly average ambient air temperature in the district of experimental work is ranged between 20.8 (December) and $39.1^{\circ} \mathrm{C}$ (July). Consequently, the designer took the worst condition in December month.

\section{Combined water heating systems.}

Solar energy cannot provide the heat energy required to secure the desired temperature, especially in winter months. Therefore, electrical energy can be operated with the solar energy to compensate this difference between the powerful of solar collector and the set point temperature $\left(75^{\circ} \mathrm{C}\right)$. The electric heat energy requirement of combined system $\left(\mathrm{Q}_{\mathrm{B}}\right)$ can be computed by:

$$
\mathrm{Q}_{\mathrm{B}}=\left(\mathrm{M}_{\mathrm{s}} / 3600\right) \mathrm{Cp}\left(\mathrm{T}_{\mathrm{s}}-\mathrm{T}_{\text {solar }}\right)
$$

\section{Comparison techniques}

The performances of each calculated model compared with the measured values of solar radiations were assessed using fundamental error analysis, such as the mean percentage error (MPE), mean bias error (MBE), absolute fraction of variance $\left(\mathrm{R}^{2}\right)$ and root mean square error (RMSE) according to (Maghrabi, 2009, and Muzathik et al., 2011).

\section{The Mean Bias Error (MBE)}

The Mean Bias Error in $\mathrm{W} / \mathrm{m}^{2}$ can be estimated based on calculated incident solar radiation $\left(\mathrm{R}_{\mathrm{c}}\right)$ in $\mathrm{W} / \mathrm{m}^{2}$, measured incident solar radiation in $\mathrm{W} / \mathrm{m}^{2}(\mathrm{Rm})$, and the number of observations $(\mathrm{N})$ as follows:.

$$
M B E=(1 / N) \sum_{i=1}^{N}\left(R_{c}-R_{m}\right)
$$




\section{The Mean Percentage Error (MPE)}

$$
M P E=(1 / N) \sum_{i=1}^{N}\left(\frac{R_{m}-R_{c}}{R_{m}} \times 100\right)
$$

\section{The Root Mean Square Error (RMSE)}

$$
R M S E=\sqrt{\frac{1}{N}\left[\sum_{i=1}^{N}\left(R_{c}-R_{m}\right)^{2}\right]}
$$

The RMSE on the other hand provides dependable information about the short-term performance, which measures the level of scattering data that produces by the model. With a lower value of RMSE refers to a good and dependable model in terms of its absolute deviation. MPE specifies the percentage deviation of the calculated and measured solar radiation data. The MBE is an indication of the average deviation of the calculated data from the corresponding measured data and can provide information on long-term performance of the models; the lower value of MBE refers to a good and dependable model. When the MPE value is positive, the calculated data are less than the measured data, and when the MPE value is negative, the measured data are lower than the calculated data (Muzathik et al., 2011). Using RMSE and MPE indicators alone causes errors in the model. So, it is recommended that besides these two indictors the criterion 't-test which compares the actual difference between two means in relation to the variation in the data (Jacovides and Kontoyiannis, 1995). The lower value of t-test is referred to a good performance. It should be noticed that the t-test in this study employed to measure the difference of values between two models. Therefore, the lowest values of t-test gave the best result.

$$
t=\sqrt{\frac{\left((n-1) \times(M B E)^{2}\right)}{(R M S E)^{2}-(M B E)^{2}}}
$$

\section{RESULTS AND DISCUTION}

The position of the sun on place in question in this present study is described by the solar declination angle $(\delta)$, solar altitude angle $(\psi)$ and solar incident angle $(\theta)$. These angles are computed for two different levels; horizontal plane and inclined surfaces $\left(30.5^{\circ}\right.$ and $\left.45.3^{\circ}\right)$ and listed in Table (3). Solar declination angle $(\delta)$ in different months for average day in each month is summarized in Table (3). The lowest value of solar 
declination angle is $-23^{\circ}$ and calculated in December 10 and the highest value of that angle is $23.1^{\circ}$ and estimated in June 11. This angle interprets the consecutive process of four seasons (winter, spring, summer, and fall). The solar altitude at noon is ranged between $36.5^{\circ}$ (on December 10) and $82.3^{\circ}$ (on June 11). When the sun is higher in the sky the light shines were directly on the surface below it. Most days, this can be observed at and around noon when the sun is directly facing a section of the globe. Thus, this solar angle is important because the solar panels rely on high amounts of solar radiation.

Table (3) also reveals that the values of solar incident angle on horizontal plane are higher than that on the inclined surfaces using two different tilt angles $\left(30.5\right.$ and $\left.45.3^{\circ}\right)$. The solar angle of incidence plays a significant and important role on solar receiver's efficiency. This angle causes foreshortening of the receivers as it effects on the effective transmittance of the glass envelope and the effective absorptance of the selective surface of solar collectors. Thereby, a higher incident angle greatly lowers the solar receiver's performance.

Table (3): Solar declination angle $(\delta)$, altitude angle $(\psi)$, incident angles $(\theta)$ at noon on horizontal and two different tilt angles, and sunshine hours $(\mathrm{N})$.

\begin{tabular}{|l|c|c|c|c|c|c|}
\hline Month & $\boldsymbol{\Delta}$ & $\boldsymbol{\psi}$ & $\boldsymbol{\theta}$ & $\begin{array}{c}\boldsymbol{\theta}, \text { with inclined } \\
\mathbf{3 0 . 5 ^ { \circ }}\end{array}$ & $\begin{array}{c}\boldsymbol{\theta}, \text { with } \\
\text { inclined 45.3 }\end{array}$ & $\mathbf{N}, \mathbf{h r}$ \\
\hline January & $-20.9^{\circ}$ & $38.5^{\circ}$ & $51.5^{\circ}$ & $21.2^{\circ}$ & $7^{\circ}$ & 10.2706 \\
\hline February & $-13.0^{\circ}$ & $41.2^{\circ}$ & $51.6^{\circ}$ & $18.5^{\circ}$ & $4.2^{\circ}$ & 10.9641 \\
\hline March & $-2.4^{\circ}$ & $57.1^{\circ}$ & $33.1^{\circ}$ & $2.6^{\circ}$ & $12.3^{\circ}$ & 11.8105 \\
\hline April & $9.4^{\circ}$ & $63.0^{\circ}$ & $26.8^{\circ}$ & $5.1^{\circ}$ & $18.8^{\circ}$ & 12.7468 \\
\hline May & $18.8^{\circ}$ & $77.7^{\circ}$ & $11.8^{\circ}$ & $19.2^{\circ}$ & $33.8^{\circ}$ & 13.5415 \\
\hline June & $23.1^{\circ}$ & $82.3^{\circ}$ & $7.4^{\circ}$ & $23.2^{\circ}$ & $38^{\circ}$ & 13.9412 \\
\hline July & $21.2^{\circ}$ & $80.8^{\circ}$ & $9.4^{\circ}$ & $21.2^{\circ}$ & $36^{\circ}$ & 13.7675 \\
\hline August & $13.5^{\circ}$ & $73.1^{\circ}$ & $17.0^{\circ}$ & $13.6^{\circ}$ & $28.4^{\circ}$ & 13.0924 \\
\hline September & $2.2^{\circ}$ & $61.9^{\circ}$ & $28.2^{\circ}$ & $2.6^{\circ}$ & $17.2^{\circ}$ & 12.1888 \\
\hline October & $-9.6^{\circ}$ & $50.0^{\circ}$ & $40.1^{\circ}$ & $9.7^{\circ}$ & $5.7^{\circ}$ & 12.0061 \\
\hline November & $-18.9^{\circ}$ & $40.7^{\circ}$ & $49.4^{\circ}$ & $18.9^{\circ}$ & $4.2^{\circ}$ & 10.4619 \\
\hline December & $-23.0^{\circ}$ & $36.5^{\circ}$ & $53.5^{\circ}$ & $23^{\circ}$ & $8.3^{\circ}$ & 10.0752 \\
\hline
\end{tabular}

A rule of thumb, when solar incident angle decreased the absorbed solar radiation increased. The numbers of maximum possible bright sunshine 
hours are the necessary elements when studying the position of the sun on research place to decide the possibility of using solar systems.

The lowest and highest numbers of bright sunshine hours, respectively, are almost 10 and 14 hours. Nevertheless, the number of maximum possible bright sunshine hours during winter season was computed under clear sky conditions without clouds. In addition, the specific characterize of each month affecting on the measured or calculated the values of solar radiation depending on the position of the sun on place in question.

\section{Solar radiation}

Solar radiation is the important component for any applications use the solar energy. Therefore, the hourly average measured and calculated solar radiation on horizontal surface for each month is plotted in Fig. (1). It evidently revealed that, the measured values are higher than that the calculated for all months. It also indicated that, the solar radiation values which calculated by ASHARAE model are higher than that calculated using Duffie \& Beckman model for all months.

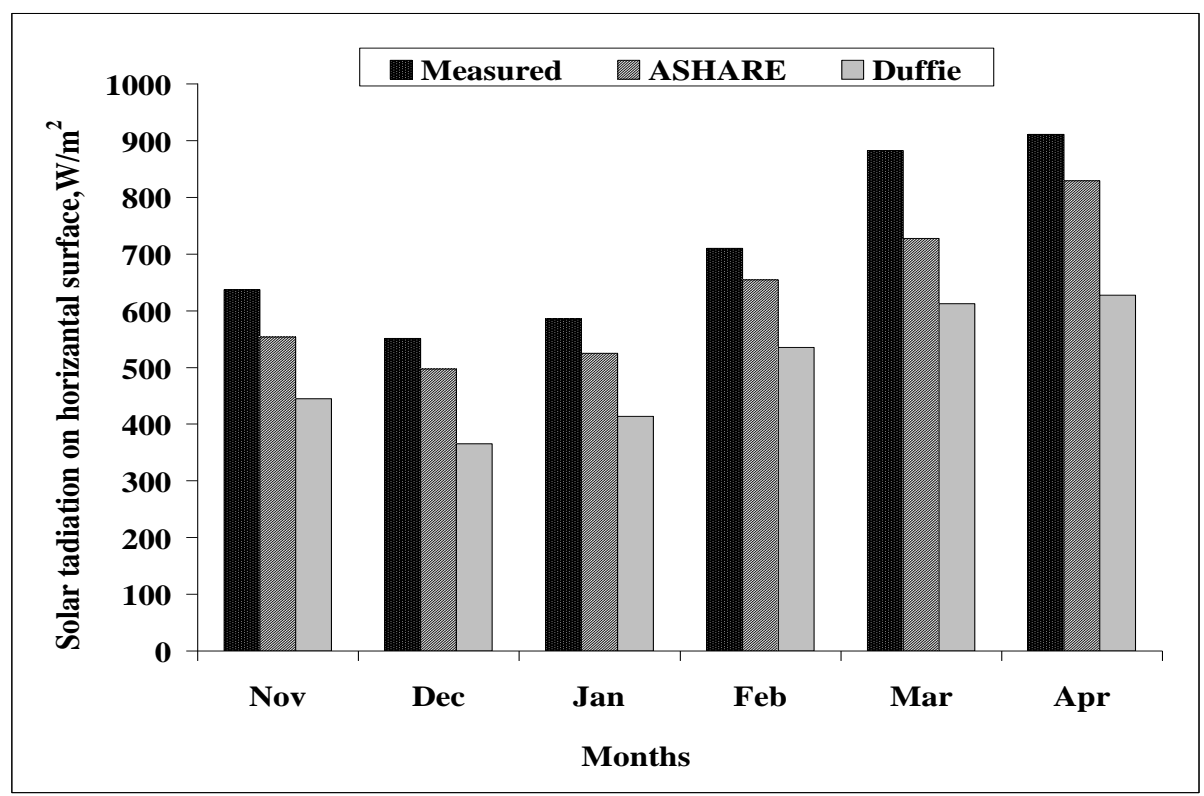

Fig. (1): Hourly average measured and calculated solar radiation by ASHARE and Duffie \& Beckman models at horizontal surface.

Fig. (2) and Fig. (3) show the relation between measured solar radiations and calculated on two different tilt angles $\left(30.5^{\circ}\right.$ and $\left.45.3^{\circ}\right)$. With tilt 
angle $30.5^{\circ}$ the measured solar radiation ranged between 837.87 and $1065.56 \mathrm{~W} / \mathrm{m}^{2}$ and by ASHARE model solar radiation ranged between 767.92 and $886.21 \mathrm{~W} / \mathrm{m}^{2}$. Calculated solar radiation by Duffie \& Beckman model ranged between 870.43 and $1102.45 \mathrm{~W} / \mathrm{m}^{2}$. With tilt angle $45.3^{\circ}$, the measured solar radiation ranged between $881.78 \mathrm{~W} / \mathrm{m}^{2}$, $1094.3 \mathrm{~W} / \mathrm{m}^{2}$ and by ASHARE model solar radiation ranged between 801.17 and $907.72 \mathrm{~W} / \mathrm{m}^{2}$, and by Duffie \& Beckman model solar radiation ranged between 935.56 and $1073.7 \mathrm{~W} / \mathrm{m}^{2}$.

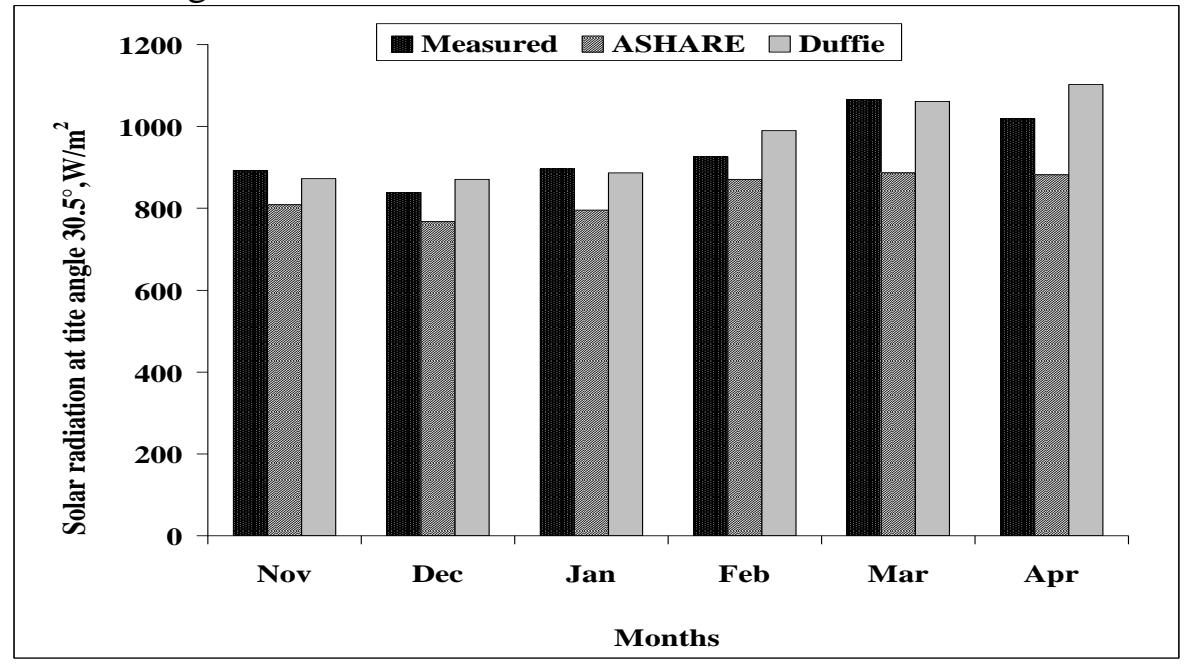

Fig. (2): Hourly average measured and calculated solar radiation by

ASHARE, and Duffie \& Beckman models with tilt angle $30.5^{\circ}$. The optimal measured solar radiation can be concluded by the linear regression between measured and calculated solar radiation throughout the year at different planes indicated that in Figs. 4, 5, 6, 7, 8, 9. To compare between these data used $\mathrm{R}^{2}$. So, Duffie \& Beckman model gave the highest values of $\mathrm{R}^{2}$ when compared it with the values of ASHARE model. But, $\mathrm{R}^{2}$ is not adequate to compare between two models. Therefore, should be used the other statistical indicators to insure the comparison test.

The validations of the data calculated using the two different models with that measured by different statistical tests are summarized and listed in Table (4). The results clearly indicated that, the reliance on the RMSE and MBE used separately can lead to a wrong decision in the selection of the best model due to the RMSE and MBE in isolation is not an adequate indicator for the model performance. Therefore, the t-test should be used 
in conjunction with these two indicators to give better evaluation for the models performance. Also, using regression analysis has the highest values of coefficient of determination $\left(\mathrm{R}^{2}\right)$ and consequently the correlation coefficient $(\mathrm{r})$, which provided good results.

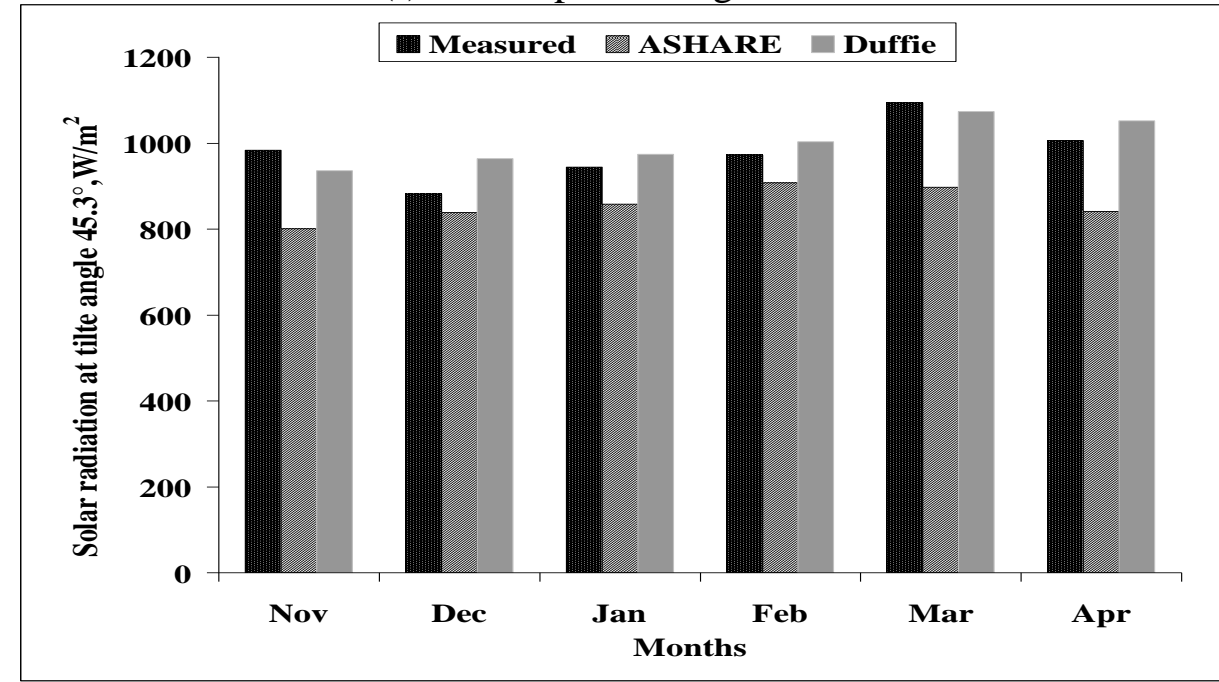

Fig. (3): Hourly average measured and calculated solar radiation by ASHREA and Duffie\& Beckman models with tilt angle $45.3^{\circ}$

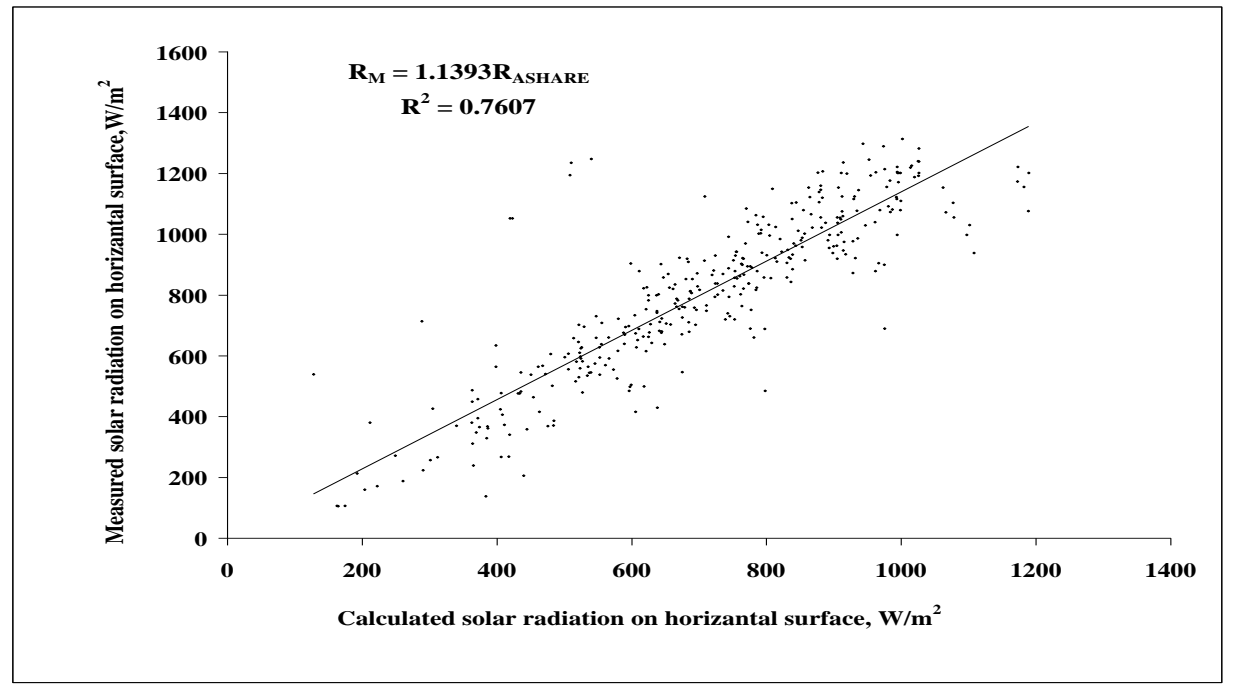

Fig .(4): Relationship between the hourly average measured and calculated solar radiation values on horizontal surface by ASHARAE model

All the hourly average calculated solar radiation by Duffie \& Beckman model was agreement with that measured on the two different tilt angles as it was gave the best results according to the statistical rules. Using 
MBE statistical indicator, gave lower value with Duffie \& Beckman model as compared with the ASHARE model. This means that Duffie \& Beckman is the best way by using this indicator. Also, the values of coefficient of determination $\left(\mathrm{R}^{2}\right)$ and consequently the correlation coefficient (r) for Duffie \& Beckman model were higher than that for the ASHREA model.

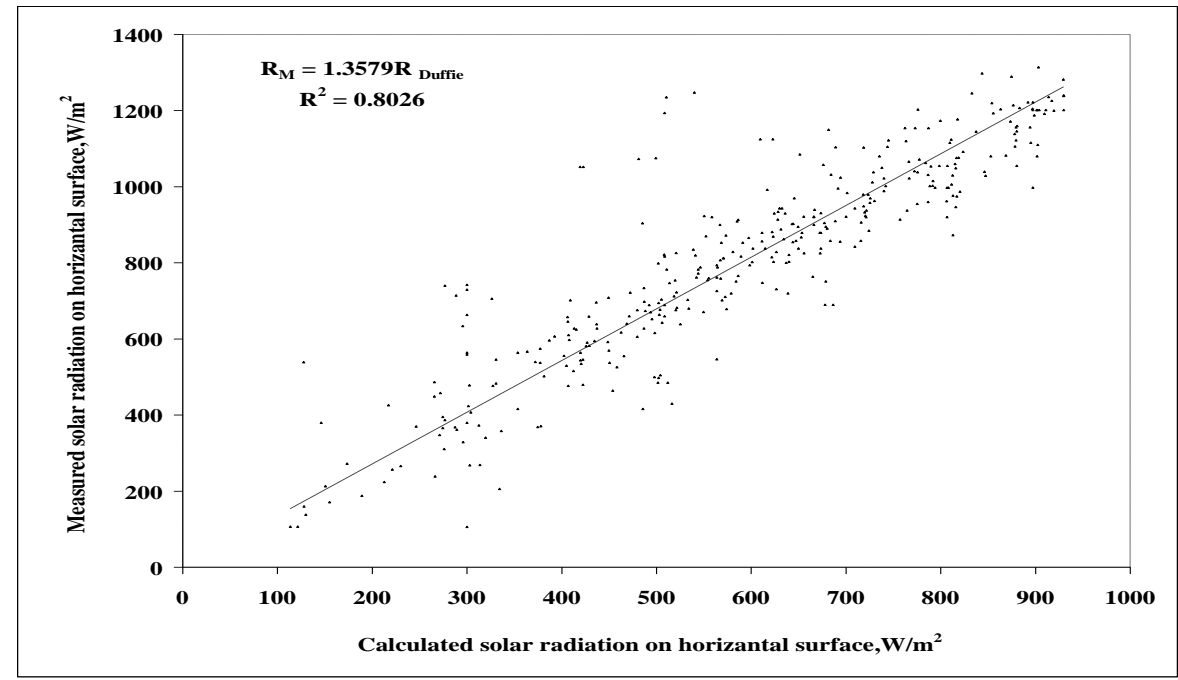

Fig (5) Relationship between the hourly average measured and calculated solar radiation values on horizontal surface by Duffie and Beckman model

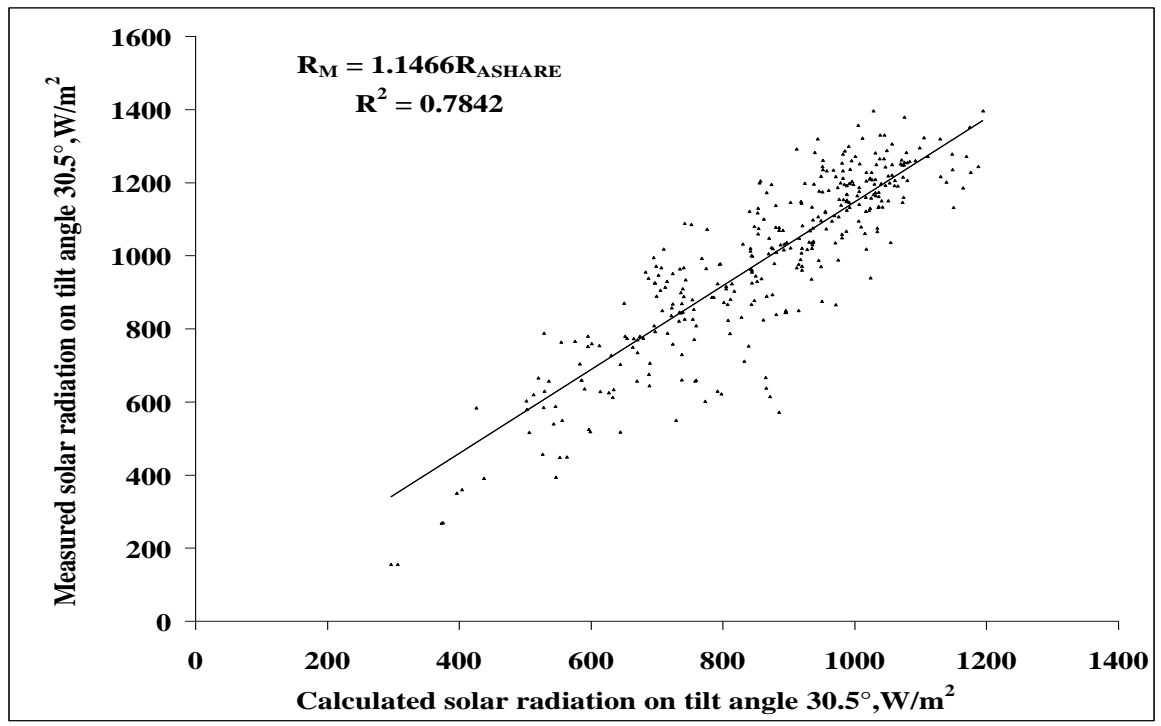

Fig (6) Hourly average measured and calculated solar radiation values on tilt angle $30.5^{\circ}$ by ASHARAE model 


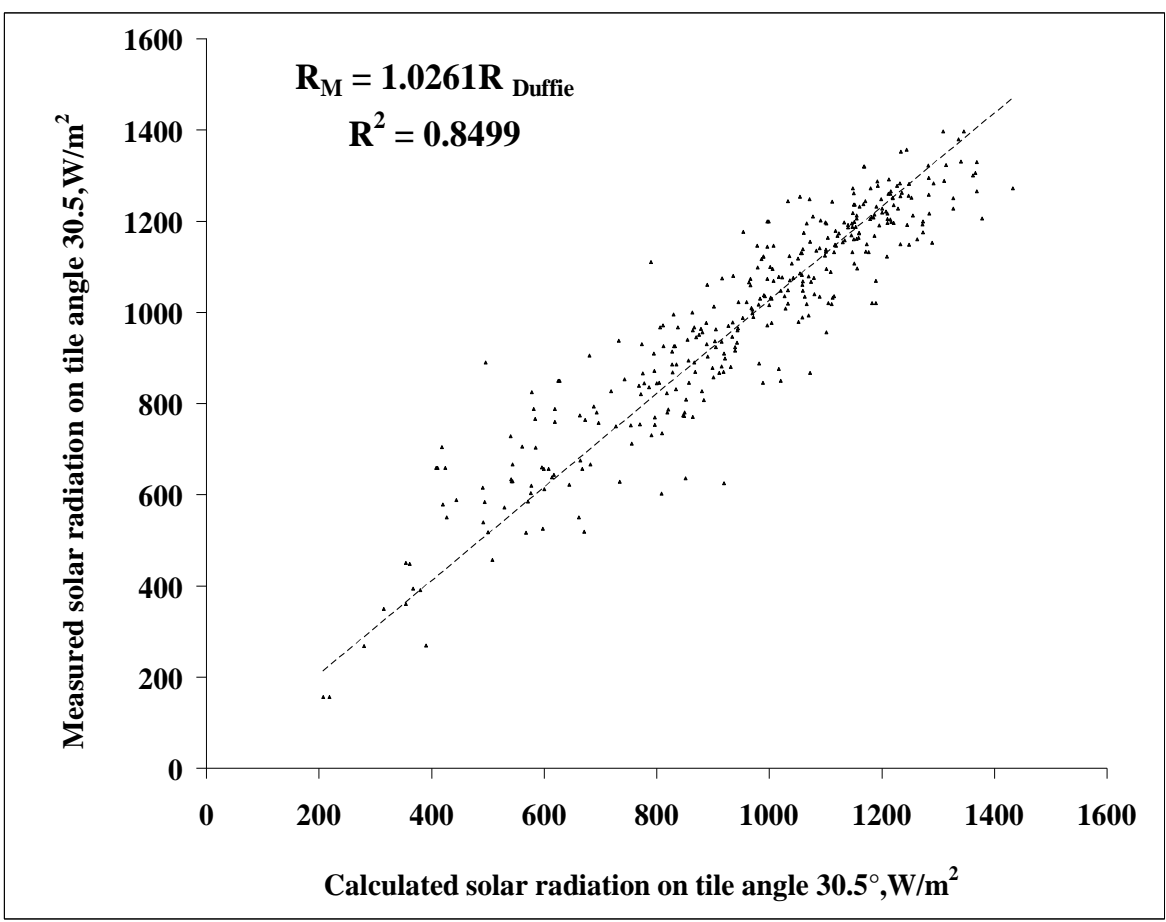

Fig (7) Hourly average measured and calculated solar radiation value on tilt angle $30.5^{\circ}$ by Duffie and Beckman model

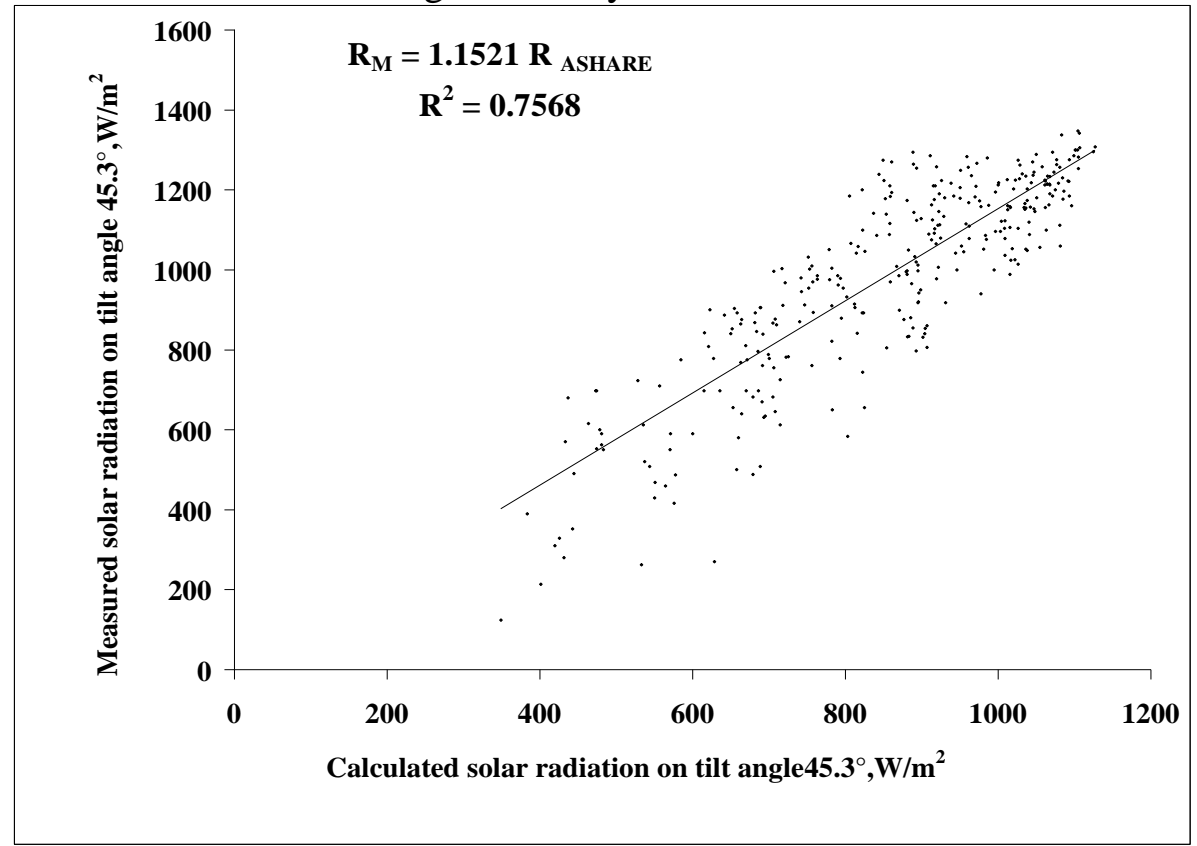

Fig (8) Hourly average measured and calculated solar radiation values on tilt angle $45.3^{\circ}$ by ASHARAE model 


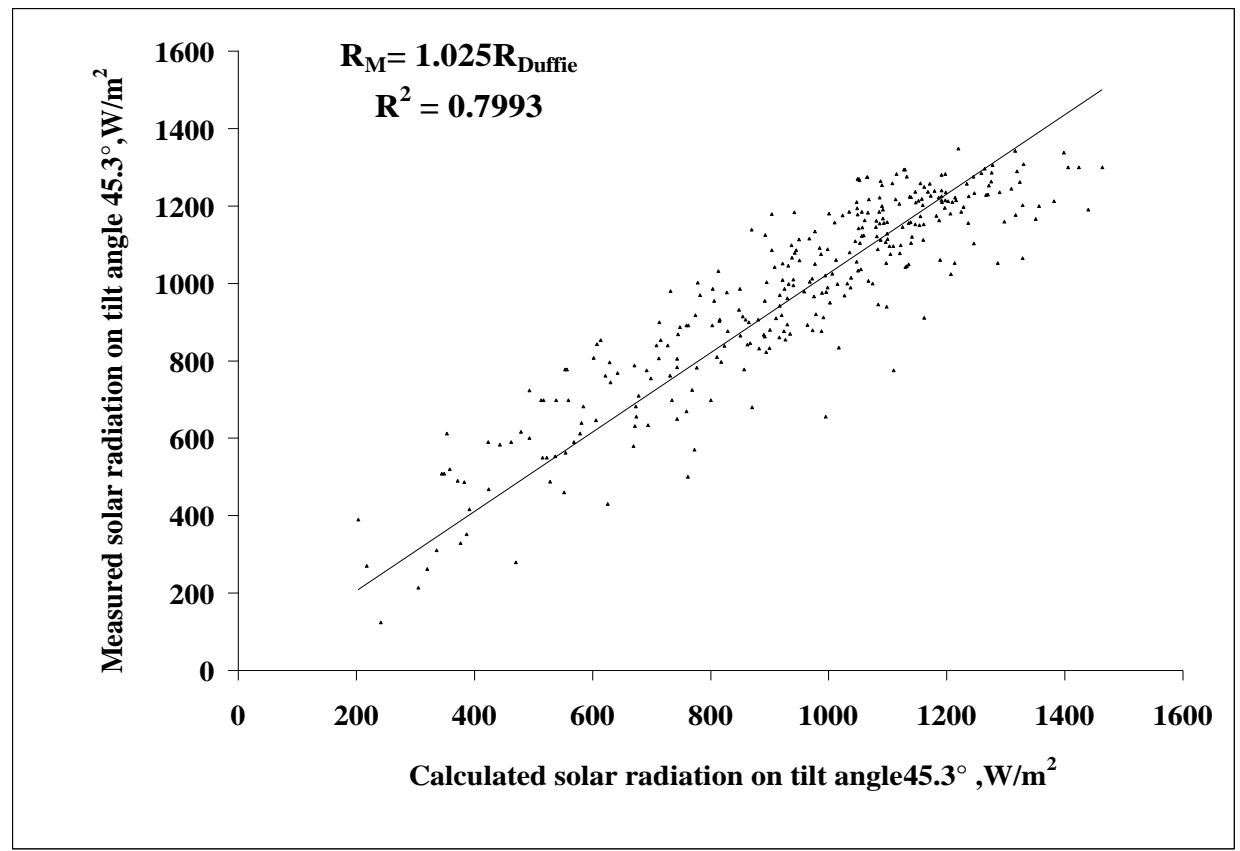

Fig (9) Hourly average measured and calculated solar radiation value on tilt angle $45.3^{\circ}$ by Duffie and Beckman model

Therefore, Duffie \& Beckman model can be used to compute the solar radiation flux incident on tilted surfaces using tilt angles of $30.5^{\circ}$ and $45.3^{\circ}$ with a good reliability. Meanwhile, the ASHARE model gave a good reliability when using it to estimate the hourly average incident solar radiation on horizontal surface according to the MPE, RMSE and t-test.

Table (4): Validation of the models under different statistical tests

\begin{tabular}{|c|c|c|c|c|c|c|}
\hline METHOD & \multicolumn{3}{|c|}{ Duffie \& Beckman } & \multicolumn{3}{|c|}{ ASHARE } \\
\hline Indicators & $\mathrm{H}$ & $30.5^{\circ}$ & $45.3^{\circ}$ & $\mathrm{H}$ & $30.5^{\circ}$ & $45.3^{\circ}$ \\
\hline MBE $W / m^{2}$ & -221.3 & -33.6 & -25.11 & -102.7 & -124.6 & -128.4 \\
\hline MPE, \% & 25.4 & 3.2 & 2.11 & 8.8 & 10.3 & 9.8 \\
\hline RMSE, W/m ${ }^{2}$ & 256.1 & 96.2 & 130.98 & 172.5 & 170.5 & 181.2 \\
\hline t-test & 32.5 & 6.9 & 3.49 & 14.0 & 19.9 & 17.9 \\
\hline STDEVA & \pm 155.3 & \pm 23.8 & \pm 17.75 & \pm 71.2 & \pm 88.1 & \pm 90.8 \\
\hline $\mathbf{R}^{2}$ & 0.804 & 0.870 & 0.7812 & 0.710 & 0.700 & 0.659 \\
\hline $\mathbf{R}$ & 0.897 & 0.933 & 0.8839 & 0.843 & 0.836 & 0.812 \\
\hline
\end{tabular}

The use of solar energy is challenge in winter season because the solar radiation has continuously changing values resulting in the nature of this 
season. Therefore, the study focused on measured and calculated values of solar radiation during each month in winter season for different planes of solar heater. The data analysis showed that each month in winter season had equation to estimate the solar radiation from the calculated data. This means that the heating requirement should be precisely determinate because the solar radiation is the basic element to calculate the total energy. Consequently, the costs were evaluated.

\section{Useful heat gain}

The useful heat gain to storage is the effective indicator to clarify the quantity of heat can be acquired from the solar heating system. Therefore, the useful heat gain to storage using measured and calculated solar radiation values with two different tilt angles $\left(30.5^{\circ}\right.$ and $\left.45.3^{\circ}\right)$ was plotted in Fig.(10) and Fig. (11). Using the measured solar radiation, useful heat gain to storage ranged between 6.54 and $8.82 \mathrm{kWh} /$ day on December and march, respectively. The useful heat gain to storage when using the calculated solar radiation by the ASHARE model ranged between 5.99 and $7.34 \mathrm{kWh} /$ day on December and March, respectively. While, the useful heat gain to storage using the calculated solar radiation by Duffie and Beckman model ranged between 6.97 and $9.00 \mathrm{kWh} /$ day on December and April, respectively with tilt angle of $30.5^{\circ}$. Useful heat energy gain with using measured solar radiation on tilt angle $45.3^{\circ}$, ranged between 7.08 and $9.06 \mathrm{kWh}$ /day on December and March, respectively. But, when using calculated solar radiation by ASHARE, the useful heat gain values ranged between $6.64 \mathrm{~kW} . \mathrm{h}$ and $7.51 \mathrm{kWh}$ on November and February, respectively. Useful heat gain when using Duffie and Beckman method ranged between 7.75 and $8.89 \mathrm{kWh} /$ day on November and March, respectively. From the previous data it can be observed that, the useful heat energy gain using Duffie and Beckman model are closest to that data using the measured solar radiation on the same tilt angle.

\section{Water heating for Domestic purposes}

Solar collector is a special kind of heat exchanger that can convert the solar radiation flux incident on it into thermal heat energy. The thermal heat energy generated by the solar collectors can be used as heating source for many applications which depends upon the desired temperature (i.e. outlet temperature from solar collector). Employing solar collector for heating water to utilize in different domestic purposes is one of the 
important applications of solar energy in rural areas instead of the electrical heaters.

Table (5) indicated the equations which used to predict the values of measured solar radiation by different models used in this study.

\begin{tabular}{|c|c|c|c|}
\hline \multirow{4}{*}{$\begin{array}{l}\text { Month } \\
\text { November }\end{array}$} & \multicolumn{2}{|c|}{ Measured solar radiation $\left(\mathrm{R}_{M}\right)$} & \multirow{2}{*}{$\begin{array}{l}\text { Tilt angle } \\
\text { Horizontal }\end{array}$} \\
\hline & $\begin{array}{l}\mathrm{R}_{\mathrm{M}}=1.1674 \mathrm{R}_{\text {ASHARE }} \\
\mathrm{R}_{\mathrm{M}}=1.4387 \mathrm{R}_{\text {Duffie }}\end{array}$ & $\begin{array}{l}\mathrm{R}^{2}=0.8871 \\
\mathrm{R}^{2}=0.9022\end{array}$ & \\
\hline & $\begin{array}{l}\mathrm{R}_{\mathrm{M}}=1.1655 \mathrm{R}_{\mathrm{ASHARE}} \\
\mathrm{R}_{\mathrm{M}}=0.986 \mathrm{R}_{\text {Duffie }}\end{array}$ & $\begin{array}{l}\mathrm{R}^{2}=0.9405 \\
\mathrm{R}^{2}=0.9431\end{array}$ & $30.5^{\circ}$ \\
\hline & $\begin{array}{l}\mathrm{R}_{\mathrm{M}}=1.1252 \mathrm{R}_{\mathrm{ASARAF}} \\
\mathrm{R}_{\mathrm{M}}=0.9833 \mathrm{R}_{\text {Duffie }}\end{array}$ & $\begin{array}{l}\mathrm{R}^{2}=0.7435 \\
\mathrm{R}^{2}=0.8877\end{array}$ & $45.3^{\circ}$ \\
\hline \multirow[t]{3}{*}{ December } & $\begin{array}{l}\mathrm{R}_{\mathrm{M}}=1.1273 \mathrm{R}_{\text {ASHARE }} \\
\mathrm{R}_{\mathrm{M}}=1.4189 \mathrm{R}_{\text {Duffie }}\end{array}$ & $\begin{array}{l}\mathrm{R}^{2}=0.7898 \\
\mathrm{R}^{2}=0.8685\end{array}$ & Horizontal \\
\hline & $\begin{array}{l}\mathrm{R}_{\mathrm{M}}=1.1268 \mathrm{R}_{\text {ASHARE }} \\
\mathrm{R}_{\mathrm{M}}=0.9666 \mathrm{R}_{\text {Duffie }}\end{array}$ & $\begin{array}{l}\mathrm{R}^{2}=0.8255 \\
\mathrm{R}^{2}=0.8612\end{array}$ & $30.5^{\circ}$ \\
\hline & $\begin{array}{l}\mathrm{R}_{\mathrm{M}}=1.0659 \mathrm{R}_{\mathrm{ASHARH}} \\
\mathrm{R}_{\mathrm{M}}=0.9053 \mathrm{R}_{\text {Duffie }}\end{array}$ & $\begin{array}{l}\mathrm{R}^{2}=0.7729 \\
\mathrm{R}^{2}=0.8066\end{array}$ & $45.3^{\circ}$ \\
\hline \multirow[t]{3}{*}{ January } & $\begin{array}{l}\mathrm{R}_{\mathrm{M}}=1.1048 \mathrm{R}_{\text {ASHARE }} \\
\mathrm{R}_{\mathrm{M}}=1.3406 \mathrm{R}_{\text {Duffie }}\end{array}$ & $\begin{array}{l}\mathrm{R}^{2}=0.8297 \\
\mathrm{R}^{2}=0.8971\end{array}$ & Horizontal \\
\hline & $\begin{array}{l}\mathrm{R}_{\mathrm{M}}=1.1307 \mathrm{R}_{\text {ASHARE }} \\
\mathrm{R}_{\mathrm{M}}=1.0132 \mathrm{R}_{\text {Duffie }}\end{array}$ & $\begin{array}{l}\mathrm{R}^{2}=0.7923 \\
\mathrm{R}^{2}=0.8614\end{array}$ & $30.5^{\circ}$ \\
\hline & $\begin{array}{l}\mathrm{R}_{\mathrm{M}}=1.0876 \mathrm{R}_{\mathrm{ASHARE}} \\
\mathrm{R}_{\mathrm{M}}=0.967 \mathrm{R}_{\text {Duffie }}\end{array}$ & $\begin{array}{l}\mathrm{R}^{2}=0.7363 \\
\mathrm{R}^{2}=0.8553\end{array}$ & $45.3^{\circ}$ \\
\hline \multirow[t]{3}{*}{ February } & $\begin{array}{l}\mathrm{R}_{\mathrm{M}}=1.1019 \mathrm{R}_{\text {ASHARE }} \\
\mathrm{R}_{\mathrm{M}}=1.3385 \mathrm{R}_{\text {Duffie }}\end{array}$ & $\begin{array}{l}\mathrm{R}^{2}=0.7815 \\
\mathrm{R}^{2}=0.8148\end{array}$ & Horizontal \\
\hline & $\begin{array}{l}\mathrm{R}_{\mathrm{M}}=1.08 \mathrm{R}_{\text {ASHARE }} \\
\mathrm{R}_{\mathrm{M}}=0.9488 \mathrm{R}_{\text {Duffie }}\end{array}$ & $\begin{array}{l}\mathrm{R}^{2}=0.8237 \\
\mathrm{R}^{2}=0.9034\end{array}$ & $30.5^{\circ}$ \\
\hline & $\begin{array}{l}\mathrm{R}_{\mathrm{M}}=1.0778 \mathrm{R}_{\text {ASHARE }} \\
\mathrm{R}_{\mathrm{M}}=0.9945 \mathrm{R}_{\text {Duffie }}\end{array}$ & $\begin{array}{l}\mathrm{R}^{2}=0.8365 \\
\mathrm{R}^{2}=0.8816\end{array}$ & $45.3^{\circ}$ \\
\hline \multirow[t]{3}{*}{ March } & $\begin{array}{l}\mathrm{R}_{\mathrm{M}}=1.2237 \mathrm{R}_{\text {ASHARE }} \\
\mathrm{R}_{\mathrm{M}}=1.4449 \mathrm{R}_{\text {Duffie }}\end{array}$ & $\begin{array}{l}\mathrm{R}^{2}=0.884 \\
\mathrm{R}^{2}=0.9044\end{array}$ & Horizontal \\
\hline & $\begin{array}{l}\mathrm{R}_{\mathrm{M}}=1.204 \mathrm{R}_{\mathrm{ASHARE}} \\
\mathrm{R}_{\mathrm{M}}=0.9937 \mathrm{R}_{\text {Duffie }}\end{array}$ & $\begin{array}{l}\mathrm{R}^{2}=0.904 \\
\mathrm{R}^{2}=0.9052\end{array}$ & $30.5^{\circ}$ \\
\hline & $\begin{array}{l}\mathrm{R}_{\mathrm{M}}=1.2224 \mathrm{R}_{\mathrm{ASHARE}} \\
\mathrm{R}_{\mathrm{M}}=1.011 \mathrm{R}_{\text {Duffie }}\end{array}$ & $\begin{array}{l}\mathrm{R}^{2}=0.8755 \\
\mathrm{R}^{2}=0.945\end{array}$ & $45.3^{\circ}$ \\
\hline \multirow[t]{3}{*}{ April } & $\begin{array}{l}\mathrm{R}_{\mathrm{M}}=1.14 \mathrm{R}_{\text {ASHARE }} \\
\mathrm{R}_{\mathrm{M}}=1.3134 \mathrm{R}_{\text {Duffie }}\end{array}$ & $\begin{array}{l}\mathrm{R}^{2}=0.901 \\
\mathrm{R}^{2}=0.9162\end{array}$ & Horizontal \\
\hline & $\begin{array}{l}\mathrm{R}_{\mathrm{M}}=1.1471 \mathrm{R}_{\mathrm{ASHARE}} \\
\mathrm{R}_{\mathrm{M}}=1.0205 \mathrm{R}_{\text {Duffie }}\end{array}$ & $\begin{array}{l}\mathrm{R}^{2}=0.8706 \\
\mathrm{R}^{2}=0.9568\end{array}$ & $30.5^{\circ}$ \\
\hline & $\begin{array}{l}\mathrm{R}_{\mathrm{M}}=1.1972 \mathrm{R}_{\text {ASHARE }} \\
\mathrm{R}_{\mathrm{M}}=1.0555 \mathrm{R}_{\text {Duffie }}\end{array}$ & $\begin{array}{l}\mathrm{R}^{2}=0.7888 \\
\mathrm{R}^{2}=0.9625\end{array}$ & $45.3^{\circ}$ \\
\hline
\end{tabular}




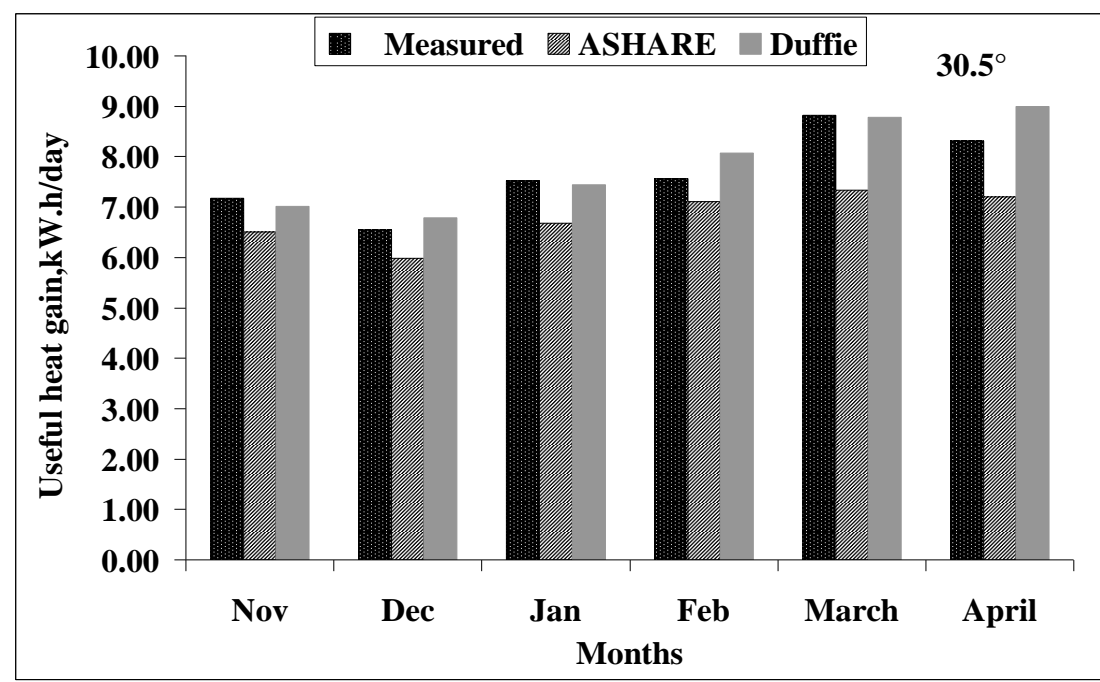

Fig. (10): Useful heat energy gain throughout the year with title angle $30.5^{\circ}$

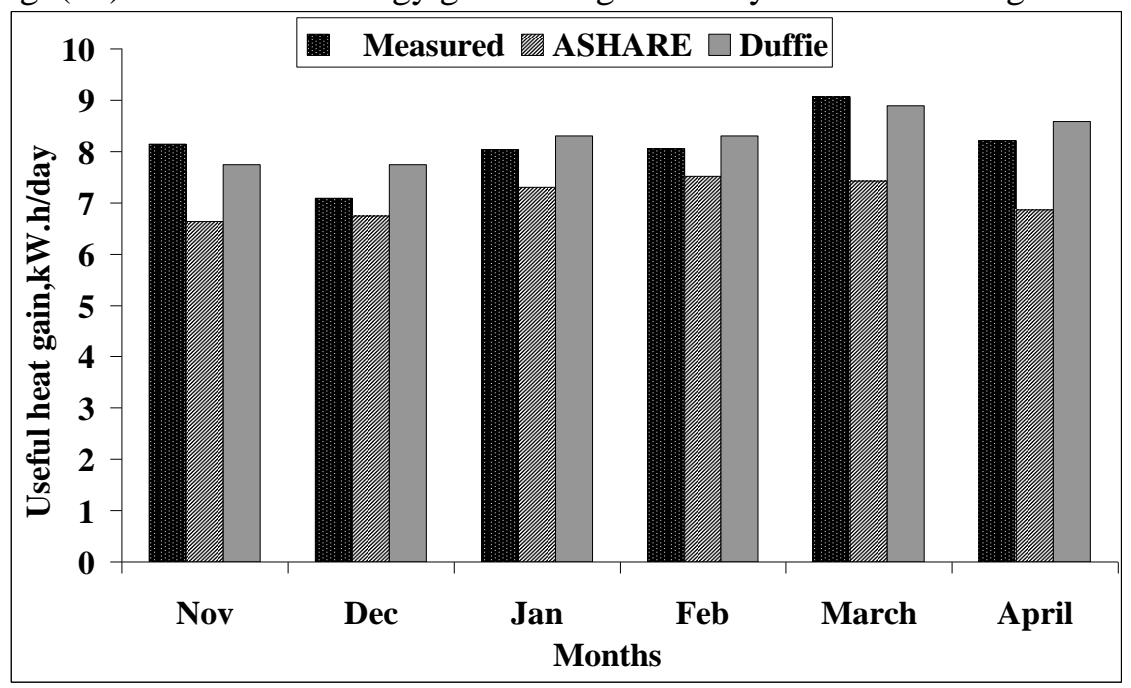

Fig.(11): Useful heat energy gain throughout the year with title angle $45.3^{\circ}$

The useful heat energy gain for one person using solar collector with two different tilt angles $\left(30.5^{\circ}\right.$ and $\left.45.3^{\circ}\right)$ is plotted in Fig. (12). The daily average useful heat energy gain per person with the two different tilt angles were ranged between 0.853 and $2.035 \mathrm{kWh}$, and 0.849 and 2.078 kWh on April and February, respectively.

\section{Electrical water heating}

Electrical water heater converts electricity to heat energy within $100 \%$ efficiency. Electrical energy consumed in water heating depends on the 
temperature difference between the set point of heater system and the diurnal average ambient temperature. The annual electrical energy consumed for water heating is plotted in Fig. (13). the highest electric energy consumed was $10.12 \mathrm{kWh}$ which occurred on January, while, the lowest value was $7.61 \mathrm{kWh}$ which occurred on April month.

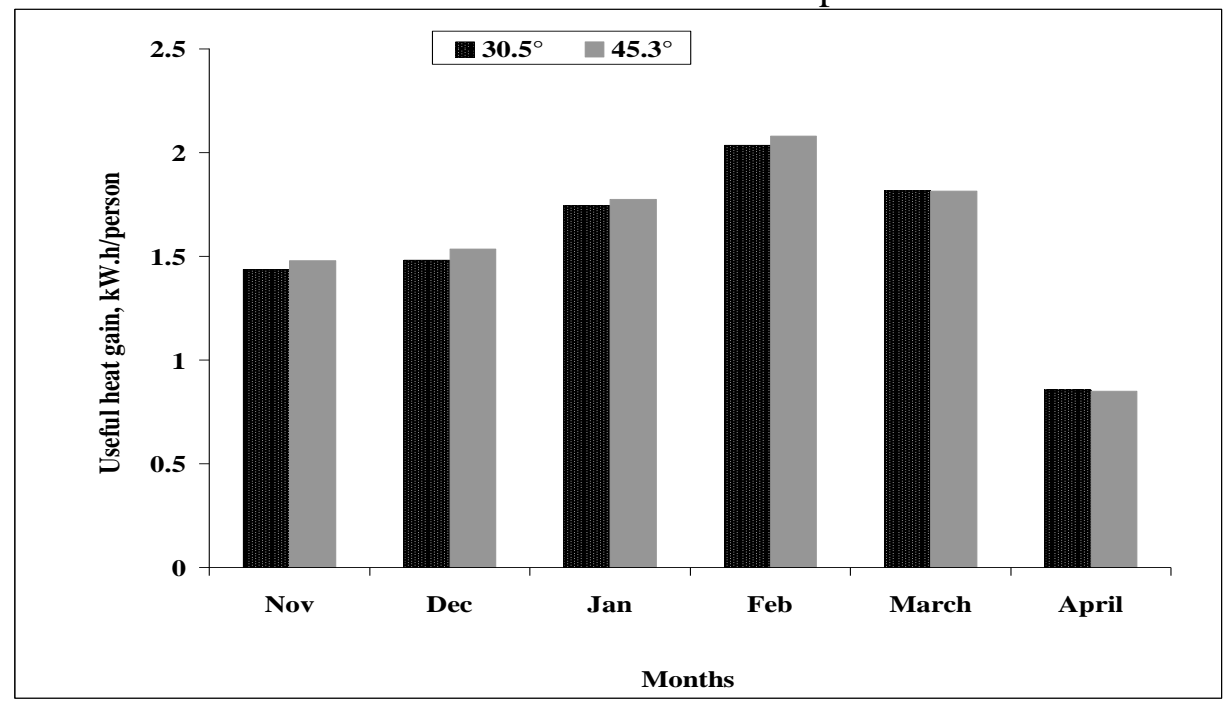

Fig. (12): Useful heat energy gain per person with two different tilt angles

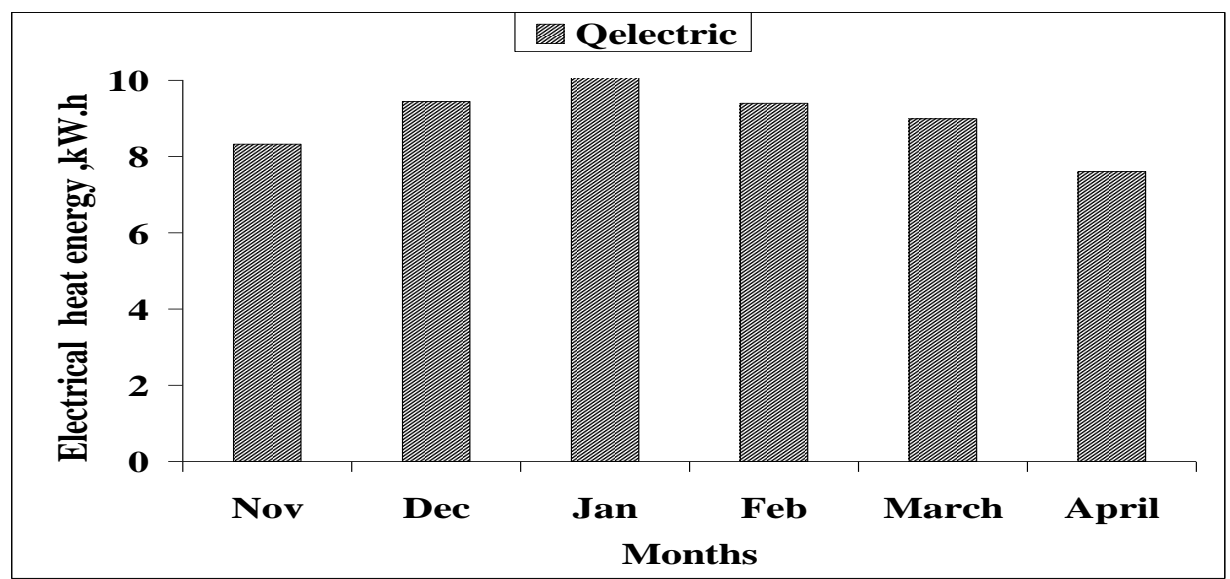

Fig. (13): Electric energy consumed for water heating

\section{Combined cycle for water heating}

Using solar collector for domestic water heating is differed from month to another because of the intensity of solar radiation, which dependent upon the climatic conditions. Solar water heating system can heat the water for domestic purposes to the desired temperature level in some times 
particularly in summer months. Nevertheless, in late fall, winter and the beginning of spring months it cannot reach the desired level of water temperature. Therefore, another heat energy source is needed and used as auxiliary electric heater to achieve the desired water temperature level. The electrical energy consumed for water heating after it was heated by the solar heating system with two different tilt angles $\left(30.5^{\circ}\right.$ and $\left.45.3^{\circ}\right)$ is plotted in Fig. (14).

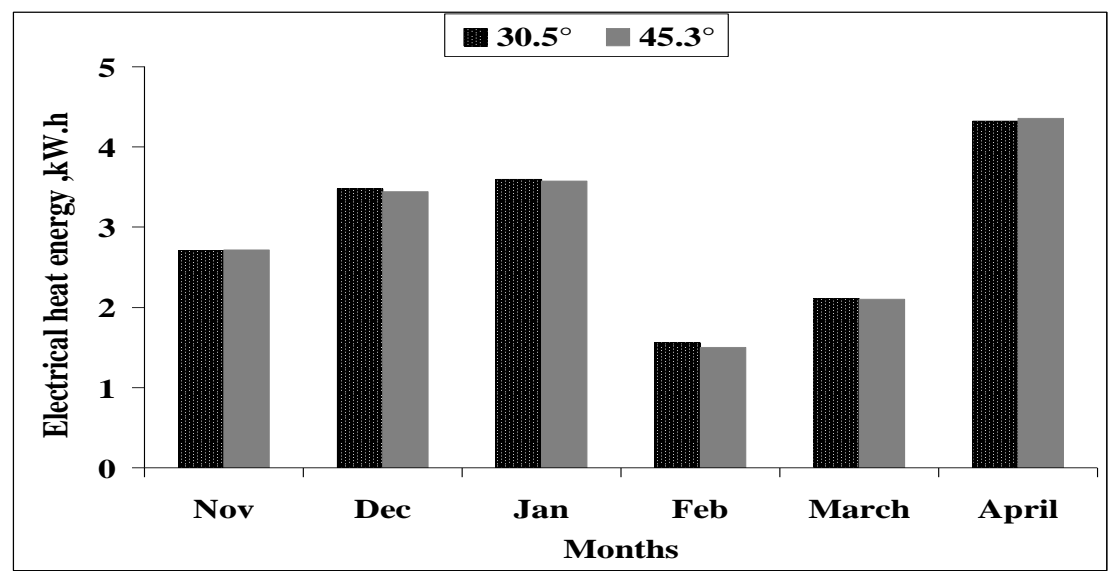

Fig (14) Combined cycle for water heating throughout year months It evidently revealed that, the highest value of electrical energy consumed to provide the desired temperature level for the two different tilt angles, respectively, was $4.32 \mathrm{~kW} . \mathrm{h}$ and $4.35 \mathrm{~kW} . \mathrm{h}$ at April.

\section{CONCLUSION}

In the present study, the hourly average solar radiation flux incident on horizontal surface and on two different inclined surfaces was calculated using two different mathematical models. The obtained results were compared with that measured data using the statistical indicators to determine the feasibility of using the mathematical model, which has a good reliability to calculating the heat energy required for water heating. The obtained results can be concluded in the following points:

1) For the place in question the solar incident angle for tilt angle $30.5^{\circ}$ ranged between $2.6^{\circ}$ and $23^{\circ}$ and for tilt angle of $45.3^{\circ}$ ranged between $4.2^{\circ}$ and $38^{\circ}$ and for horizontal plane it ranged between $36.5^{\circ}$ to $82.3^{\circ}$.

2) Calculated solar radiation using Duffie \& Beckman model was higher than that calculated by ASHARE model on both tilt angles. In addition, calculating solar radiation using Duffie \& Beckman model was found to be closest to the measured data. 
3) The hourly average useful heat energy gain per person when using tilt angle $45.3^{\circ}$ was higher than that the tilt angle $30.5^{\circ}$ by $1.77 \%$ in winter season.

4) The electric energy provided by auxiliary heater for heating water was ranged between $7.61 \mathrm{kWh}$ and $10.12 \mathrm{kWh}$ at April and January, respectively.

5) Electrical energy consumed in combined heating system using auxiliary heater was ranged between 1.55 and $4.32 \mathrm{kWh}$ on February and April for tilt angle $30.5^{\circ}$, respectively, and 1.5 and $4.35 \mathrm{kWh}$ on February and April for tilt angle $45.3^{\circ}$, respectively.

\section{REFERENCES}

Amrutkar, S.; S. Ghodk; and K. N. Patil (2012) "Solar flat plate collector analysis" IOSR Journal of Engineering (IOSRJEN), Vol. 2, No. 2: 207-213.

ASHARAE HANDBOOK (2005) "Fundamentals: Fenestration, Chapter 31.1791 TULECIRCLE NE, ATLANTA,GA 30329.

Atlas (2018) http://global solaratlas.info/downloads on 20/8/ 2018

Azadeh, A.; A. Maghsoudi; and S. Sohrabkhani (2009) "An integrated artificial neural networks approach for predicting global radiation" Energy Conversion Management, 50(6): 1497-1505.

Besharat, F.; A. A. Dehghan; and A. R. Faghih (2013) "Empirical models for estimating global solar radiation: A review and case study" Renewable and Sustainable Energy Reviews, Vol. 21: 798-821.

Chasma-ard, W.; S. Suckchai; S. Sonsaree; and S. Sirisamphanwong (2014) "Thermal performance testing of heat pipe evacuated tube with compound parabolic concentrating solar collector" by ISO 9806-1,Energy procedia,Vol.56:237-246.

Darwesh, M.; A. H. Elmetwalli; A. Derbala; T. Fouda; and M. Moraed (2010) "Construction and thermal performance evaluation of flat plate solar collectors" The $17^{\text {th }}$ Annual conference of the Misr Journal of Agricultural Engineering, Vol. 8. 1922-1937

Darwesh, M. (2015) "Thermal performance test of evacuated tube and flat plate solar collectors under climatic conditions of Egypt" Misr Journal of Agricultural Engineering,Vol.32,No. 4:1717-1756.

Duffie, J. A.; and W. Beckman (2006) "Solar engineering of thermal processes" J. Wiely and Sons. 
El Mghouchi, Y; A. El Bouardi; Z. Choulli; and T Ajzoul (2014) "New model to estimate and evaluate the solar radiation" International Journal of Sustainable Built Environment, Vol.3.No.2: 225-234.

Fouda, T. Z.; M. Darwesh; and N. Gremida (2016) "Study on the thermal performance of evacuated solar collector system" Misr Journal of Agricultural Engineering. Vol. 33, No. 2: 589-602.

Jacovides,C.Pand H, Kontoyiannis.1995 .T-test procedures for the evaluation of evapotranspiration computing models; Agric. Water Manag.Vol. 27,No. 3,pp: 365-371.

Maghrabi, A. H.2009. "Parameterization of a simple model to estimate monthly global solar radiation based on meteorological variables, and evaluation of existing solar radiation models for Tabouk, Saudi Arabia," Energy Conversion and Management, vol. 50, no. 11, pp. 2754-2760.

Muzathik, A.M ,.2011. "Daily global radiations estimate based on sunshine hours", International Journal of Mechanical and Materials Engineering, vol.6,No.1, pp:75-80.

National Renewable Energy Laboratory (NREL). 2010. Office of Energy Efficiency and Renewable Energy. Optimizing Rooftop Space with Solopt. Salt Lake City, Utah:

Retrievedfromhttp://solaramericacommunities.energy.gov/pdfs/201 0_annual_meeting/Th. u400_SWH_LLisell.pdf.

Prada, A.; G. Pernicotto.; P. Bacggio.; A. Gasparella and A. Mahdavi. (2014). Effect of solar radiation model on the predicted energy performance of buildings. $3^{\text {th }}$ International high performance buildings conference at Purdue, July 14-17, 3486, 10pp.

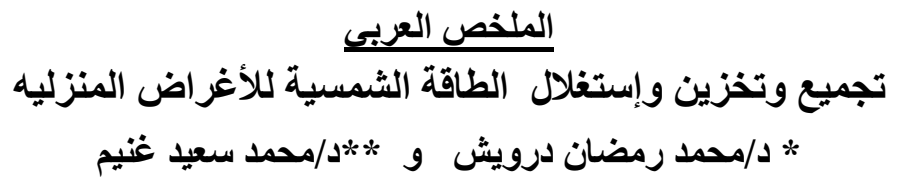

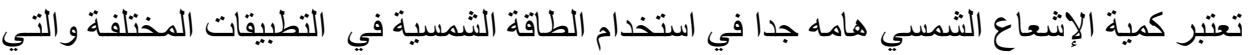

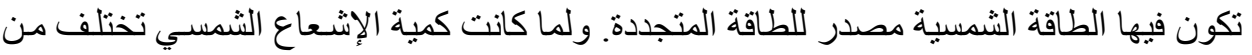

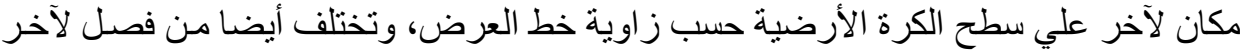

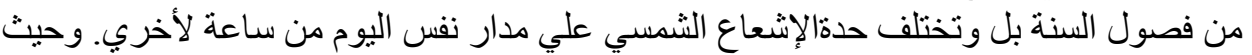

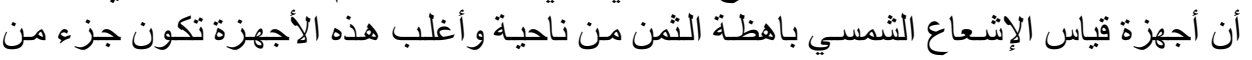
محطات الأرصاد الجوية من ناحية أخري.

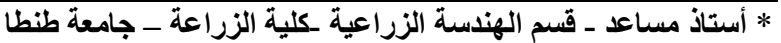
* * مدرس ـ قسم الهندسة الزراعية ـكلية الزراعة - جامعة طنطا لزاعل 
وأيضا فإن هذه الأجهزة لا تمكن المصمم أو الباحث من اعطاء بيانات دقيقة إذا تطلب الأمر إلي معرفة كمية الإشعاع الشمسي علي سطح مائل و التي تتطلب وجوب لإنس تعديل القياس من سطح أفقي الي ما يعادله علي سطح مائل. ولذا فإن هذا البحث يهدف إلي در اسة تطابق نموذجين رياضيين لحسـاب متوسط السـاعة للطاقـة

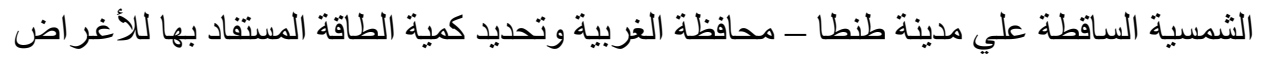
المنزلية.

وتـم استخدام النمـوذج الرياضـي ل Duffie\& Beckman و النموذج الرياضـي ل ASHARE

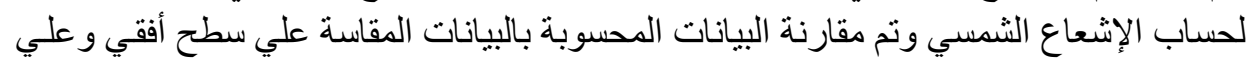

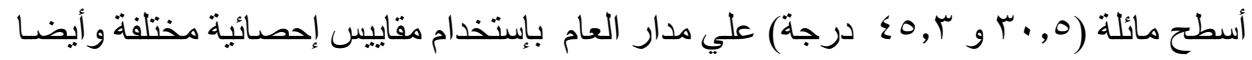

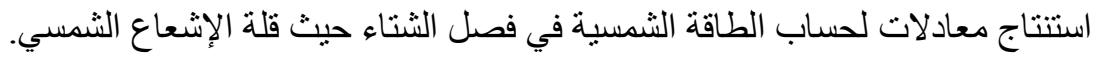
وكانت أهم النتائج المتحصل معلاد عليها هي:

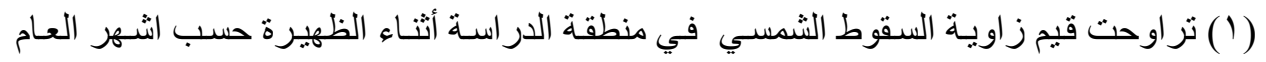

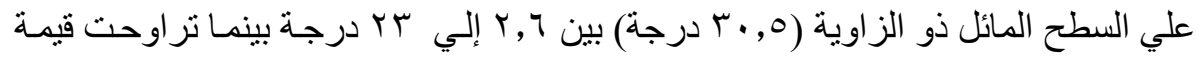

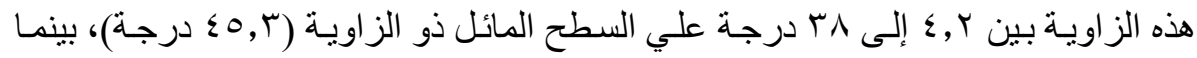

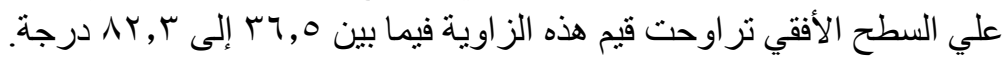

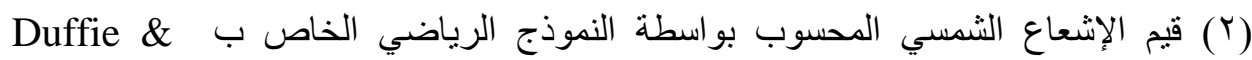
Beckman ASHARE

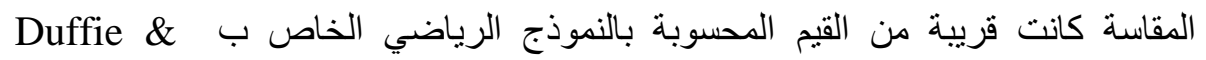
. Beckman

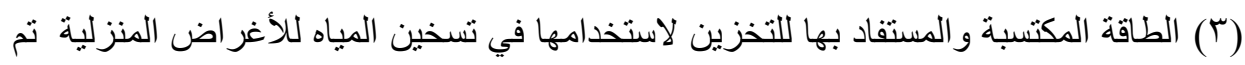

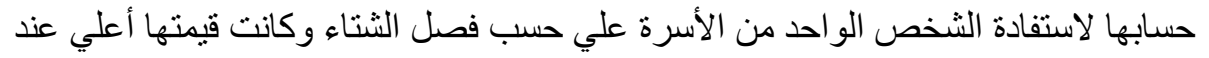

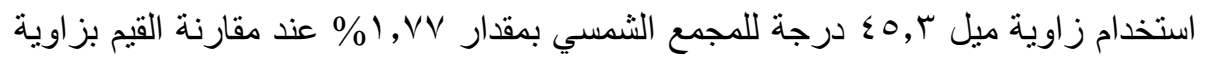

$$
\text { ميل 0, • مب درجة. }
$$

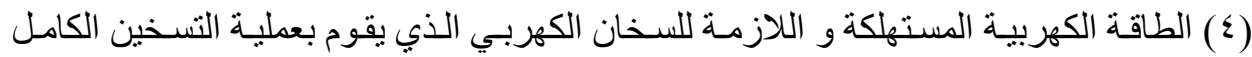

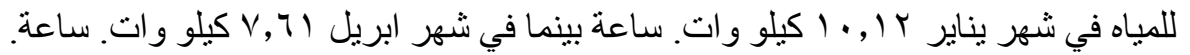
(0) الطاقـة الكهربيـة المسـتهلكة في حالـة اسـتخدام السـخان الكهربـي لإكمـال عمليـة التسـخين

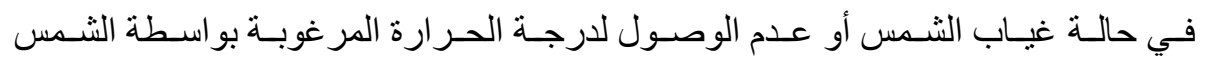
فكانت الطاقة المستهلكة في شهر فبر اير بr ك, كيلو وات. ساعة بينما في شهر ابريل

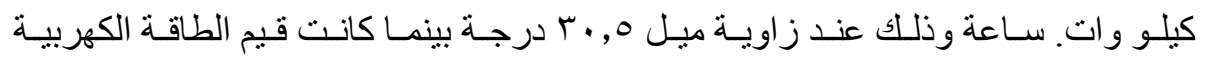

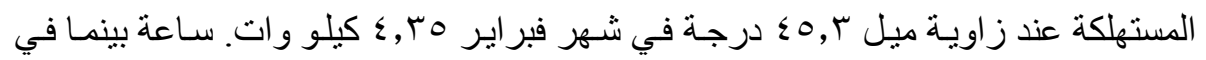

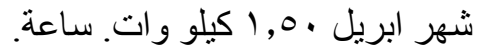

